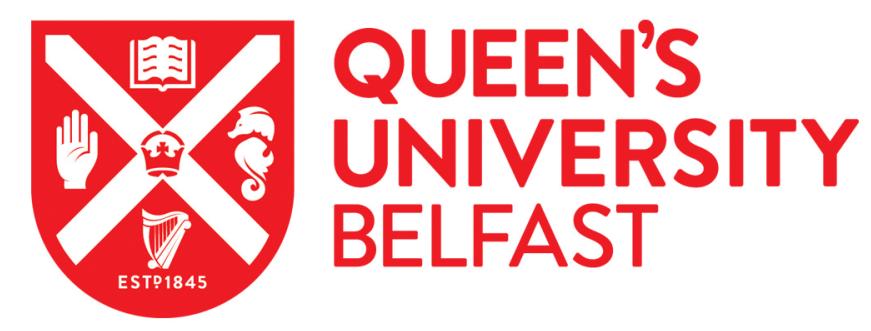

\title{
Practice Running Ahead of Theory? Political Economy and the Economic Lessons of UK Devolution
}

Brownlow, G. (2017). Practice Running Ahead of Theory? Political Economy and the Economic Lessons of UK Devolution. Cambridge Journal of Regions, Economy and Society, 10(3), 559-573.

https://doi.org/10.1093/cjres/rsx015

\section{Published in:}

Cambridge Journal of Regions, Economy and Society

\section{Document Version:}

Peer reviewed version

\section{Queen's University Belfast - Research Portal:}

Link to publication record in Queen's University Belfast Research Portal

\section{Publisher rights}

(C) The Author 2017.

Published by Oxford University Press on behalf of the Cambridge Political Economy Society

This work is made available online in accordance with the publisher's policies. Please refer to any applicable terms of use of the publisher.

\section{General rights}

Copyright for the publications made accessible via the Queen's University Belfast Research Portal is retained by the author(s) and / or other copyright owners and it is a condition of accessing these publications that users recognise and abide by the legal requirements associated with these rights.

Take down policy

The Research Portal is Queen's institutional repository that provides access to Queen's research output. Every effort has been made to ensure that content in the Research Portal does not infringe any person's rights, or applicable UK laws. If you discover content in the Research Portal that you believe breaches copyright or violates any law, please contact openaccess@qub.ac.uk. 


\title{
Practice Running Ahead of Theory? Political Economy and the Economic Lessons of UK Devolution
}

\begin{abstract}
Advocates of political decentralisation make much of its supposed 'economic dividends'. Critics of this argument, while acknowledging the possible benefits, suggest that the specific 'institutional geography' under which devolution operates is crucial. In short, the Institutionalist critique is that economic outcomes are contingent on the way devolved institutions are designed. The institutional geography of contemporary UK devolution, as well as the historical case of Northern Irish devolution (1920s-1972), is analysed in this paper. Contemporary and historical evidence as well as theoretical material presented provides further support for the hypothesis that institutional structures are crucial.
\end{abstract}

Keywords: Institutional Geography, Devolution, Tiebout, Kaldor, Fiscal Federalism, Rebalancing

JEL Codes: H11, O17, R19, R50 


\section{Introduction}

The vote for Brexit in June 2016 requires that the UK has to work out how to operate in a world after European Union (EU) membership. The Devolved Administrations (DAs) covering the devolved regions/territories of the United Kingdom (UK), as well as the central government, have been particularly eager to find out what exactly the Prime Minister's statement that 'Brexit means Brexit' will mean in practice.1 Events have run ahead of some of the assumptions underpinning what is taught regarding EU economics.2 By analogy since the late 1990s those whose teaching responsibilities require them to teach about the financial and economic settlement associated with UK devolution have faced a similar situation. Bailey and Budd's recent excellent survey of the implications of the reorganising and restructuring of economic territories within the UK was written before the referendum result (Bailey and Budd, 2016). They, and other authors within that book, observed that economists seeking insights on UK devolution can get valuable insights from a variety of branches within economics, including fiscal federalism and agglomeration analysis (Bell, 2016).3

There is a strong tradition in favour of political decentralisation/devolution articulated around the works of Tiebout, Musgrave and Oates among others - this tradition contends that devolution improves economic performance (Ashcroft, 1998; Pike, RodríguezPose, Tomaney, Torrisi and Tselios, 2012). Mechanisms, including inducing shifts toward allocative and productive efficiency may explain this 'economic dividend' (Hamlin, 1991; Rodríguez-Pose and Bwire, 2004).4 As we will see, examples of the 'economic dividend' hypothesis are influential within discussions on extending the scale and scope of tax devolution within the UK (Booth, 2015).5 Yet those academic studies that examined or tested the hypothesis have found little empirical support (Rodríguez-Pose and Bwire, 2004, p.1908).

Hamlin argued that we need to break the 'economic dividend' argument into two parts a decentralisation and competition thesis (Hamlin, 1991). The former being that a decentralised government can vary tax and spend bundles in a Tiebout type process, while the competition thesis is related, and suggests that competing governments will compete with each other for voter citizens in a way analogous to competitive markets. Hamlin noted that such approaches pay insufficient attention to the variety and complexity of the procedural models that exist within any real world decentralized political arrangements. Hamlin concluded that such was the complexity of the real world that a better approach was to create what he termed an interdisciplinary 'comparative institutional analysis' (Hamlin, 1991, p.204).

In this paper we agree with Hamlin's misgivings and relate his discussion to the concept of 'institutional geography'. The term is difficult to define; 'institutional geography' has been summarised as involving "past evolutions of spatial disparities, spatial economic policy, and decentralisation within the political economies of particular nation-states. The historical dimension of the analysis is critical in understanding the path dependencies that shape the evolution of institutional structures and policy approaches over time and space, reflecting legacies of political choices, strategies, and struggles' (Pike, Rodríguez-Pose, 
Tomaney, Torrisi and Tselios, 2012, p.12). Hence institutional geography as form of 'comparative institutional analysis' can be said to involve the following observations:

A) A recognition of the importance of the general institutional structures of a county (as in the New Institutional Economics) (North, 1990);

B) A recognition of the importance of the institutional structures at the sub-national level;

C) Due to A) and B) there is a recognition that institutional geography is connected to the historical uniqueness of each specific location;

D) The recognition that institutional geography in no way implies optimality in observed institutions, but it does imply that contingency is important in understanding observed outcomes.

In short, institutional geography demonstrates that it is not simply decentralisation that matters, it is the institutional arrangements that underpin it that will determine its success or failure. The UK case, writers influenced by the concept have used it to demonstrate that devolution need not be efficiency-enhancing (Rodríguez-Pose and Gill, 2005).6

The structure of the paper is as follows, in the first section, the concept of institutional geography is developed as a critique of the 'economic dividend' hypothesis. It will be demonstrated that the economic consequences of devolution are contingent on the institutional geography under which the respective DA operates. The focus then shifts in the second section towards the (ir) relevance of Tiebout (1956) as applied to UK devolution. Tiebout's sorting model implies that political decentralisation at the level of local government can promote economic efficiency. Tiebout's insight has been used by advocates of greater fiscal decentralisation in the UK (Booth, 2015). The observation is made that political decentralisation as practised in the UK, with its associated institutional geography, increases the gap between Tiebout's assumptions and the observed outcomes.

In section three the institutional geography interpretation is contrasted with the influential Kaldor (1970) discussion. Applied to the example of the UK's patchwork or asymmetric devolution settlement, Kaldor was too simplistic in terms of its analysis of fiscal transfers; his recognition of the role of regional competitiveness remains valuable, however. Kaldor underestimated the way that different regions would have different institutional geographies and hence varying degrees of lobbying power.

In the final section the concept is applied to contemporary policy debates. The role of institutional geography in creating and preserving the so-called 'Barnett formula' settlement is discussed. A key case study developed in the final section concerns the proposals advocating devolving Corporation Tax (CT) powers to the Northern Ireland Assembly (NIA). If we consider the region's specific institutional geography, the economic dividend arguments for devolving CT are found particularly wanting. The paper then concludes that while there may be sound reasons to promote political decentralisation, its economic benefits are far from inevitable. 


\section{Institutional Geography and 'Economic Dividends'}

As the introductory section to this paper will have made clearer, institutional geography perspective does not view the efficiency-benefits of devolution as being inevitable (Rodríguez-Pose and Gill, 2003; 2004, 2005; Pike, Rodríguez-Pose, Tomaney, Torrisi and Tselios, 2012). Rodríguez-Pose and Gill surveyed the alleged economic advantages of devolution (Rodríguez-Pose and Gill, 2005, pp.408-10). While they acknowledged that there are 'undeniable possible benefits' from a devolved system, they also suggested that there are also 'significant costs' (Rodríguez-Pose and Gill, 2005, pp.410).7 Problems of soft budget constraints can also be placed in the category (Rodríguez-Pose and Gill, 2005, p.416). Rodríguez-Pose and a range of co-authors additionally emphasise that the relative 'legitimacy' of government tiers can determine the net economic benefits (Rodríguez-Pose and Bwire, 2004; Rodríguez-Pose and Gill, 2005, p.415). In the case of weak legitimacy, it would tend to lead to central government decentralising expenditure responsibilities on a static, and often narrowing, financial base: strong regional legitimacy tends to favour a more rapid decentralisation of resources (Rodríguez-Pose and Gill, 2003, p.334). As a consequence, all other things remaining equal, poor (strong) political support for the devolved region would translate into relatively weak (strong) regional legitimacy.

This emphasis on contingency within the institutional geography approach finds corroboration in the 'laboratory' of the 'Stormont' regime (c1921-1972) as well as more contemporary 'laboratory' of asymmetric devolution in the UK. The argument of RodríguezPose and Gill finds application in explaining the causes and consequences of rent-seeking in Northern Ireland (NI) (Crafts, 1995; Brownlow, 2007).8 These empirical studies suggest that between 1945 and 1963 the institutional geography of the DA was associated with cronyism, rent-seeking, devolution and this resulted in slow regional economic growth.9 A number of economists, writing from a variety of perspectives, have considered the specific financial and economic failings of the Stormont settlement (Rowthorn, 1981; Gibson, 1996). As a result the institutional-economic nexus has been explained as contributing to the region's economic failings (Gibson, 1996; Heald, 2003). Gibson, for instance considers that such a nexus may contributed to the creation of soft budget constraints (Gibson, 1996). It was hence the region's institutional geography which may go much of the way in explaining the poor economic outcomes. The Northern Irish model of devolution was until the outbreak of violence presented as having more general implications for the UK as a whole (Furniss, 1975, p.391). We do not posit a series of generalizations based on a particular experience; however, it is the case that the evidence warrants several propositions that are potentially relevant to contemporary UK devolution.

\section{[Insert Table 1 Here]}

As Table 1 demonstrates, while there has been some convergence of income per head; the gap has never closed fully in nearly a century. Economic performance in NI, as measured in terms of income per head relative to Britain, been of variable quality under both devolution 
and 'direct rule': there has been no clear 'economic dividend' (Birnie and Brownlow, forthcoming). The persistence of a gap - combined the fact that the gap has narrowed and widened during periods of both devolution and direct rule - suggests that neither 'economic dividend' hypothesis nor the neoclassical model provides a convincing description of Northern Irish economic development.

Likewise, the issue of 'legitimacy', emphasized by Rodríguez-Pose and his various co-authors, has implications for studying devolution. The devolved public finance settlement became more generous after 1945 (Lawrence, 1965). Partly this was the result of World War 2 exposing the relative backwardness of public housing, child welfare and tuberculosis prevention in NI. The principal criterion in determining public expenditure after 1945 became whether a particular expenditure commitment was justified in itself, rather than the pressure exerted by the notional idea of a balanced budget (Green, 1979, p.17). Expenditure on education, health and welfare all increased threefold between 1945 and 1963, while industrial promotion expenditure grew fivefold during the same period (Lawrence, 1965).

In line with the focus of Rodríguez-Pose and Gill on the connection between legitimacy, lobbying power and decentralisation of responsibilities, this change in the financial settlement after 1945 may be explained in terms of changes in legitimacy. Ollerenshaw has written about how an effect of the Second World War was to consolidate the status of NI within the UK and to ensure greater financial support from London to finance devolution (Ollerenshaw, 2013, pp.229-31). After 1945, as manufacturing grants in NI became relatively more generous, the so called 'inducement gap' widened between NI and GB (Harris, 1991). Consistent with the institutional geography thesis we interpret this change in legitimacy being mirrored in the shifts within public finance and the greater autonomy within the conduct of regional industrial policy. Archival evidence shows that maintaining the gap was a deliberate policy of the NI government and that it was HM Treasury (HMT) that was most concerned with the existence of the inducement gap for the Development Areas found in GB. As tax reliefs in the Republic of Ireland became increasingly generous, so policy makers in Belfast became concerned to preserve the inducement gap because of tax competition concerns.10

\section{Devolution, Institutional Geography and Tiebout Sorting}

An example of where 'economic dividend' reasoning needs to confront the institutional geography of devolution is Tiebout's influential discussion (Tiebout, 1956). Tiebout's analysis is an extension of market reasoning to competing jurisdictions and Tiebout himself was explicit about this when discussed the choices made by 'consumer-voters' (Tiebout, 1956, p.420).11 The economistic core of Tiebout's model - that near optimal provision and allocation of local public goods can result from mobile voters making locational choices (analogous to consumers) between competing local jurisdictions offering different 'bundles' of taxation and public services - has excited debate on the structure of local authorities (LAs) in the UK (Kay and Marsh, 2007; Dowding, 2008). Advocates of 
'economic dividend' insights see Tiebout sorting as contributing to governmental efficiency (Booth, 2015, pp.27-28).

Debates on the merits of Tiebout as applied to the UK, while making for interesting political economy insights about local government, have rarely been extended to discussing the connections (or lack of) between Tiebout and devolution.12 Devolution necessarily complicates the institutional geography implicit within the Tiebout model by adding an intermediate tier (DA) between central government and the LAs. This is a lacuna in the analysis as Tiebout mechanisms, if they exist, would be of relevance to competing DAs (just as they are alleged to be of relevance to competing LAs). Here we wish to identify how Tiebout is influential within 'economic dividend' type arguments, how it could be extended to devolution at the level of region or territory (rather than local government) and then illustrate how institutional geography tends to complicate the picture in ways that reduce the applicability of the model.

The predictions of Tiebout's model rest on a range of assumptions. One of these is that the larger (smaller) the number of competing jurisdictions, the more (less) homogenous each jurisdiction will be. One implication of devolution is that pressure for uniform standards within a DA should increase as the devolved regions and territories want to assert their autonomy. If this push to uniformity of LAs occurs within a DA, and following the model's logic, so mobility within a devolved entity would decline. Debates on devolution of tax have developed with little regard to the other DAs. The UK government has managed its relations with each devolved government bilaterally, with no overarching strategy (Trench, 2013, p.7). So for example, advocates of devolving taxation powers in NI have tended to ignore the implications for the rest of the UK (Budd, 2016). It is therefore entirely possible that greater autonomy between DAs may reduce the uniformity of tax-spending bundles offered in LAs in different parts of the UK. If this is the case, and again following the Tiebout approach, it suggests greater incentives to migrate between DAs. However, the reality is probably even more complicated than this LA-DA distinction.

In terms of the extent of UK migration, it is worth noting that moves between LAs dwarf migration between the constituent parts of the UK. There were an estimated 2.85 million residents moving between local authorities in England and Wales in the period July 2014-June 2015. The same level was shown in the previous 12-month period. In contrast, during the same period there were only 53,200 moves from England and Wales to NI and Scotland, compared with 45,600 in the opposite direction (ONS, 2015). In any case, interregional income tax differentials may not induce interregional migration (Bell and Eiser, 2014). The extent to which Tiebout type migration between the constituent parts of the UK would be induced depends in part on the extent to which high-income earners would respond to higher tax by working less, rather than migrating, and the extent to which any interregional tax differences are reflected in housing price differentials (Birnie and Brownlow, forthcoming).

Tomlinson's discussion of Scottish political economy observes the links between devolution and deindustrialisation (Tomlinson, 2014). Tomlinson observed that as an economic legacy of the pattern of Scottish industrialisation, it had been strongly influenced by globalisation. Decisions affecting the region's economy were hence primarily made 
outside of Scotland. Deindustrialisation initiated a process of long-term structural change that reduced Scotland's influence by the global economy. Tomlinson notes that Scottish industrial employment (excluding construction) between 1964 and 2014 as a share of total employment shrank from 42 per cent to 11 percent (Tomlinson, 2014, p.173). Tomlinson suggests that it was not a coincidence that deindustrialisation coincided with a greater role for the public sector. London's perceived failure to reverse Scottish industrial decline acted as a boost to calls for self-government and independence (Tomlinson, 2014, pp.173-74). As an economic response, public sector employment was created to provide economic stability. Economic historians of Scotland have noted that it fared well in public spending terms during the second half of the twentieth century (Lee, 1995, p.134). More controversially the evidence suggests that Scotland's industrial decline coincided with it increasingly having a weaker fiscal balance than the UK as a whole (McCrone, 1999, p.34).

Tomlinson observed furthermore that the growth of Scottish public sector employment was in part obscured by the Office for National Statistics (ONS) definition being based on where control lies, rather than by ownership. Hence General Practitioners on this ONS definition are for example not included as part of the public sector. In contrast, academic researchers have suggested an alternative definition. This alternative measure implies if more than half of a Scottish entity's activities are publicly funded it is deemed part of the public sector (Buchanan et al, 2009). In Table 2, using data from 2012, Tomlinson notes how on either measure, Scotland's relatively closed public sector dwarfed its (exportorientated) industrial sector.

[Insert Table 2 Here]

The benefit of a relative shift towards the public sector away from manufacturing was that employment levels were maintained; this economic stability was not costless. While the post-industrial Scottish economy was 'insured' by public spending, and with devolution ensuring these spending decisions were locally made, the revenue to pay for this expenditure came via the Barnett formula. Tomlinson contended that this new devolution settlement created an asymmetry between getting and spending. Decision-making for much of the public sector has switched to Edinburgh: Scotland's economy became both de-globalised and deindustrialised. Tomlinson's analysis raises a further hurdle between the assumptions required to make the Tiebout model hold. With public spending decisions increasingly made within Scotland, incentives to emigrate are reduced as a by-product of improved Scottish job prospects. The institutional geography of Scottish devolution is hence inconsistent with a Tiebout sorting process.

\section{Devolution, Institutional Geography and the Kaldor Model}

In the neoclassical model, assuming identical production functions in all regions, labour flows from low-to high wage regions and capital flows in the opposite direction. Such flows continue until factor returns are the same in both regions. So given certain assumptions, 
trends in regional growth will lead to an eventual convergence in regional per capita incomes (Richardson, 1978, p.137).13 Kaldor's influential discussion of the need for activist regional policy was a critique of this model (Kaldor, 1970). Kaldor assumed first that increasing returns to scale in manufacturing would lead to cumulative causation. Such cumulative causation would determine relative prosperity. The process of cumulative causation in interregional trade would determine relative rates of industrial development. The result would be that regional economies over time would diverge rather than converge with each other. Within Kaldor's model the competitiveness of a region's export base is key; other things being equal, regions are likely to become specialized in the sectors in which they are most competitive (Gardiner, Martin, Sunley and Tyler, 2013, pp.11-12). The first part of Kaldor's thesis thus starkly contrasts with the conventional neo-classical analysis.

The second component within Kaldor's analysis - one with important implications for evaluating devolution - was his assumption that it was the relative need of regions that would determine the size and direction of 'automatic' fiscal transfers (such as unemployment benefits) between regions (Gardiner, Martin, Sunley and Tyler, 2013, p.11). Kaldor however saw limits to centrifugal effects. Therefore there was a need for 'discretionary' state intervention in the form of activist regional policy that would supplement the 'automatic' income transfers (Gardiner, Martin, Sunley and Tyler, 2013, pp.11-12). So with a national budget in balance (implying that at a national level public expenditure is equal to tax revenues), tax would be equal to public expenditure in regions with average prosperity (Kaldor, 1970). Tax per capita would be above average in richer regions and public expenditure per capita would be above average in poorer regions.14

The first component in Kaldor's argument drew on Myrdal; hence it had scope for a role for institutional structures in explaining the operation of cumulative causation. The second component assumed it was only relative need that determined fiscal transfers. In terms of interpreting UK regional development, the most recent empirical estimates of regional GDP for Great Britain between 1911 and 2001 demonstrate a U-shaped curve rather than a pattern of persistent convergence or divergence (Geary and Stark, 2015; 2016). Geary and Stark suggest a long-term trend of declining regional inequality that endured until the 1970s, with a trend reversal between 1911 and sometime between 1931 and 1951 (Geary and Stark, 2015; 2016). Their analysis indicates that the U-shaped inequality curve had its origins in the nineteenth century.15 Kaldor's prediction that the scale of fiscal transfer is driven by relative prosperity furthermore does not conform to UK evidence either (Mackay, 2003, p.312). This failure provides further clues to developing an institutional economics of UK devolution. Bell's observation is particularly relevant: in addition to need, the UK may pay a premium to the devolved 'Celtic Fringe'. The centre is able to pay such a "premium" because the fringe is relatively small (Bell, 2008). Likewise, Scotland and NI's more favourable treatment relative to Wales in terms of fiscal transfers could in part be interpreted as reflecting a greater need by the centre to offer "premias" for these jurisdictions.

So rather than fiscal transfers being directly proportionate to the income per head enjoyed in each respective regions, as Kaldor posited, instead there is a 'corridor' of possible outcomes with institutional geography being crucial in determining where each respective regional/territorial income-transfer equilibrium rests. The fiscal transfer process is far less egalitarian than Kaldor assumed because institutional geographies differ within a country. 
The reality is that the respective levels of fiscal transfers are not solely determined by relative need, relative lobbying power will also differ. Even if we accept the existence of cumulative causation in determining economic divergence between regions, it is the case that a model of political economy may better explain actual outcomes in terms of the observed regional income-fiscal transfer equilibrium. The 'confidence and supply' deal agreed in June 2017 between the Conservative government and the Democratic Unionist Party, with the associated extra public expenditure for NI, is merely a recent example (Gudgin, 2017).

\section{Devolution, Institutional Geography and Fiscal Federalism}

In the previous two sections we have established that the UK model of devolution, with its associated institutional geography, adds complexities to some influential theoretical models in the area of public finance and regional economics. These issues mean that practice is running ahead of theory in the sense that institutional geography ensures that some of the predictions of these models need substantial revision. As we will also see in this section, the long-run historical 'laboratory' of devolution in NI supports the institutional geography perspective rather than the 'economic dividend' hypothesis.16 Following on from the discussion in the previous section, the institutional geography of the Barnett formula was shaped by the fact that it predated by around two decades the creation of the three new DAs.17

Space precludes an extended discussion of the Barnett formula and in any case for the interested reader there are some very good extended formal and informal discussions of its operation and consequences (Heald, 2003; Bell and Eiser, 2014; Bell 2016; Keep, 2016). However, there is a large academic literature on Barnett covering its technical properties, advantages, disadvantages and alternatives (Trench, 2013; Bell, 2016). The Barnett formula is non-statutory and was introduced in 1979 in Scotland and NI, and a year later in Wales (Rumbul, 2016). Originally it was created as a temporary measure, the formula calculates changes to the 'block grant' provided to each DA based on expenditure on comparable services in England, and on the size of the population covered by each respective DA (Rumbul, 2016, p.118). The formula is hence not directly needs-based and is based on English departmental spending. These features have led to persistent criticisms (Keep, 2016). It has been suggested that Scottish and Northern Irish support for retaining the formula (and Welsh opposition to it) is connected to the relative public expenditure outcomes that results from the formula (Rumbul, 2016, pp.118-19). Furthermore, even though the Scottish Parliament is to experience increased revenue raising powers, the formula looks likely to remain unchanged (Keep, 2016).

HMT is particularly keen to preserve this part of the institutional geography of the UK devolution settlement, whatever its inefficiencies, because it allows HMT to focus on other economic policy issues. Moves to more decentralised forms of tax devolution would reduce HMT influence; giving HMT full discretion would not be compatible with devolution. The status quo thus has a 'second best' element to it from the vantage point of intergovernmental relations between the central government machinery of Whitehall and the DAs. In any case, Olson's (1965) approach, and in particular the influential concept of collective action, 
suggests that because the DAs are relatively small, more generous public-sector provision relative to situation predicted by Kaldor - is not excessively expensive for central government. However, the insight about the relative concentration of benefits and costs predates the Barnett formula. Archival evidence for instance on the issues of coal price/freight subsidies for NI suggests that during the 1950s and 1960s it was not the overall (low) cost and concentrated benefits of such policies that were an obstacle to their implementation, instead the issue was that such policies would be extended to other peripheral regional economies raising the potential costs for HMT.18

As a consequence of the gap illustrated in Table 1 (and reflecting the earlier discussion regarding Kaldor), the total level of public expenditure has long exceeded the tax receipts generated in NI (Rowthorn, 1981). In recent years, the 'net fiscal balance' recorded a figure equal to approximately a third of GVA. The UK national equivalent for 2011-12 was 10.1\% (Department of Finance and Personnel, 2014). A more competitive private sector would improve the state of the fiscal balance in NI. Greater competitiveness would enable firms to sell more output generating jobs, which in turn would reduce the need to pay out welfare expenditures, and with greater employment and revenue the region's tax base would grow (and the corresponding subvention would decline). Improvements to underlying levels of competitiveness would also be associated with higher FDI inflows. So in this light the publication in July 2016 of the first NI Competitiveness report made sobering reading. That report compared 2014 with the 2009 performance. Table 3 illustrates that NI's relative position changed little.

\section{[Insert Table 3 Here]}

However, this overall stability masks areas of relative deterioration. Both labour supply and employment and education and skills - areas vital to productivity - are areas where there was relative deterioration. So the absence of any clear progress in regional competitiveness suggests that there will not be any improvement in the NI fiscal balance any time soon.

In stark contrast to Scotland and Wales there has not been a consideration of fiscal devolution across the entire range of taxes. Recently the debate has been confined to the reduction of Corporation Tax (CT) in NI relative to the rest of the UK (Budd, 2016). Advocates of devolving CT recognise that by the 2010s the NI economy was characterised by low skills, productivity and wages in the private sector with a correspondedly relatively large public sector (ERGNI, 2010, pp.1-3;8-15).19 Proponents of CT variation/reduction went further than this supply-side diagnosis. They argued, in accordance with the classic 'economic dividend' hypothesis, that only the lower rate of CT - based on granting greater powers to the DA - would provide the appropriate cure to the region's economic malaise (ERGNI, 2010, p. 4).

Proponents of varying CT thus present it as a 'game changer' (or 'silver bullet') that will improve economic outcomes in the region (Budd, 2016). Yet this proposed 'cure' is also subject to an institutional geography critique.20 The first major study of the potential for fiscal decentralisation in NI, and its more recent updates, applied the criteria set out by the Holtham Commission (NICVA, 2013; Birnie and Brownlow, forthcoming). These criteria included promotion of accountability and avoiding harm to economic and administrative 
efficiency. This approach led to a reduction to two dimensions: impact and feasibility. The main driver of impact would be revenue streams while the feasibility was driven by administrative costs. As Figure 1 outlines, CT, despite its dominance of economic policy discourse, is by no means the tax with the best impact-feasibility combination.

\section{[Figure 1 Here]}

Some within the business community and the voluntary sector in NI have cast doubt on the suitability of devolving CT (PwC, 2011; NICVA, 2013). The consensus from academic economists - in line with institutional geography arguments - is that enhanced power over CT should be viewed not as a 'game changer' (i.e. a solution in its own right), but as a potentially useful supplement to a broader supply-side strategy focused on boosting competitiveness (Budd, 2016). Institutional geography explains why the cost-benefit calculus of devolving CT is not the simple 'game changer' presupposed by its supporters.21 It is not symmetrical, the costs are more predictable than the benefits. So for instance, the Azores judgement implies a cost in terms of adjusting the block to match the CT revenue raised. Such costs would be considerable and fairly immediate.22 In addition, there are less predictable, but very concrete, compliance and administrative costs.

The relevance of a sequencing argument to institutional geography is that it tends undermine the popular 'silver bullet'/'game changer' narrative. FDI inflows while affected by $\mathrm{CT}$, are more generally affected by the underlying conditions that predate any CT changes. Even if FDI is 'footloose', merely lowering the regional rate of CT, without focusing on raising the region's level of competitiveness, the problem illustrated in Table 3, is just another example of the problematic 'economic dividend' hypothesis. Unlike in Scotland and Wales, NI has not had official reports on the respective merits of different forms of tax devolution. 23

In terms of the institutional geography of NI, the collective action insight again has much to commend it as a potential explanation for the pursuit of this 'economic dividend' argument (Budd, 2016; Birnie and Brownlow, forthcoming). The relative concentration (and diffusion) of costs and benefits is key. Political leaders recognise that the proposal has substantial support within the business community. Hence it is understandable that they would not spend time and effort developing electorally unrewarding policy alternatives to CT variation. Likewise, the potential concentrated benefits to business interests of greater profitability explain its popularity; they will find it easy to organise lobby groups. In contrast, the possible losers from the proposal to reduce CT-for example, those who would be adversely affected by the public expenditure reductions associated with devolving CT will be less well organised. 


\section{Conclusions}

In the conclusion to this paper we mention some of the constitutional political economy issues brought up by UK institutional geography. For example, North Sea oil and gas have become a major part of the Scottish independence debate because financial and economic issues have played such an important role in debates over Scotland's constitutional future (McCrone, 2014). In contrast to most other developed economies, the UK's fiscal relationships are not part of an explicit codified mechanism as part of formal constitution law (Bell, 2016, pp.39-40). Indeed, it has been observed that 'devolution has been shoehorned into the existing UK constitutional framework' (Gallagher, 2016, p.17). This piecemeal approach, while it is not without disadvantages, does at least provide flexibility. It might be observed for example that many of the recent changes in tax devolution within NI and Scotland have been made possible by the lack of a formal codified constitution.24

Bell's (2016) pre-Brexit observations were that proposals regarding tax devolution were based on political responses to constitutional challenges and that such a starting point is not a sensible one. He noted - in an analysis much institutionally richer than Kaldor - that compared to other developed countries, the UK was not consistent on ensuring fiscal equity across its regions and territories (Bell, 2016, p.54). Events since then have not changed the validity of this evaluation. In terms of North Sea oil, and its links to constitutional political economy, it might be speculated that part of HMT support for continuing with the Barnett formula was due to its previous contribution to overall UK tax revenues.25 However, equally the decline in oil price since 2014 has not led HMT to rethink its support for Barnett. Moreover, the decline in oil price has made Scottish public finances look much more fragile with all the constitutional implications that entails (Bell, 2016, pp.52-53; Gallagher, 2016).

In the introduction to this paper the observation was made that the development of devolution in the UK coincided with the recognition of the need for spatial and structural rebalancing. Evidence appears to suggest that first the UK model of economic growth is an inherently geographically uneven one (McCann, 2016). The growth gap between 'North' and 'South' has tended to widen during periods of national boom (Gardiner, Martin, Sunley and Tyler, 2013). Second, differences in structural composition between 'North' and 'South' have exerted influence on spatial imbalance. Third, region-specific or competitiveness factors have contributed to a widening 'North-South' gap. Consequently, just over three quarters of a century on from the Barlow Commission's Report, spatial imbalance remains a problem in the UK economy. It is against this background that 'economic dividend' arguments look even less plausible in the context of an asymmetrically devolved UK. The institutional geography of UK devolution remains piecemeal; this lack of a coordinated settlement for the whole of the UK is likely to remain the case regardless of the future direction of Brexit. The result of this analysis is that excessive claims to generality within FGFF and SGFF run up against context specific institutional geographies. Economists should bear this finding in mind when developing UK devolution economics further. 


\section{FOOTNOTES}

1 While the UK as a whole voted in favour of Brexit, in the case of both Scotland and NI a majority of the electorates in those jurisdictions voted for remain.

2 Existing textbooks on European economic integration do not serve as satisfactory manuals on the relationship between the DAs and central government as they were written on the assumption of continued EU membership.

3 Likewise, McCann's recent analysis of spatial inequality in the UK considers the place of devolved governance within this imbalance (McCann, 2016). For insights into deindustrialisation and spatial inequality within the UK economy see (Gardiner, Martin, Sunley and Tyler, 2013).

4 For good surveys of the economics of political decentralisation (see Hamlin, 1991; Oates, 2005). For a discussion of the relevance of Second Generation Fiscal Federalism (SGFF) applied to Scottish devolution see Bell (2016).

5 Early examples of papers concerning institutional aspects of Scottish devolution see Ashcroft (1998) and Keaney and Hutton (2000).

6. Rodríguez-Pose and Gill place particular emphasis on which government bodies are driving the devolutionary efforts and the institutional arrangements of each respective region and territory. Furthermore, according to this perspective, the balance of costs and benefits is contingent on the institutional geographies under which devolution operates (Rodríguez-Pose and Gill, 2005, p.417). For more on closely related issue of the relationship between theory and practice within devolution economics see papers by Bell (2008, 2016).

7 Rodríguez-Pose and Gill found three categories of cost (or risk) were particularly prevalent: inefficiency, inequity and institutional burdens. Rodríguez-Pose and Gill argue that the impact can be damaging to national efficiency as competitive bidding for FDI flows leads to a deadweight loss at the aggregate level (RodríguezPose and Gill, 2005).

8 Brownlow found that the absence of conflict of interest regulations that existed under the devolved settlement - when combined with the strong overlap between business and political elites - tended to promote rent-seeking (Brownlow, 2007).

9 Lawrence viewed the potential accessibility of political actors within NI as a strength of the Stormont settlement. In particular, he praised the way that 'businessmen and interest groups of all kinds can press their cases on the spot' (Lawrence, 1965 p.167). For a more pessimistic interpretation see (Brownlow, 2007; Ollerenshaw, 2013, p.224).

10 For more details see the documents held in the file entitled 'Financial relationship between UK and Northern Ireland', T224/1818 held by The National Archives.

11 In the Pareto efficient equilibrium people distribute themselves in communities on the basis of their preferred bundle (Rosen, 2005, p.509). Each consumer-voter receives their preferred bundle; consequently government intervention is not needed to attain efficiency (Hamlin, 1991; Kay and Marsh, 2007).

12 For an optimistic recent discussion of the links between Tiebout sorting and devolution see Booth (2015).

13 For textbook discussions of the neoclassical model of regional growth, migration and the contrasts with the Kaldor (1970) cumulative causation approach see Richardson (1978), pp.135-44; 147-50; 155 or Armstrong and Taylor (2000), pp.94-95; pp.141-43.

14 For a discussion of the public finance implications of Kaldor's model see (Mackay, 2003).

15 Geary and Stark do not provide an explanation for their empirical findings, but from a policy perspective it is notable that for regions outside the South East the golden age coincided with the Second World War and period of the long boom until the 1970s rather than the more liberalised (globalised) UK economy of the late twentieth century (Geary and Stark, 2016). After 1979 activist regional policy fell out of favour. Indeed under the influence of the so-called New Economic Geography (NEG) some economists have even argued against policies 
aimed at greater regional balance in incomes and economic growth (Gardiner, Martin, Sunley and Tyler, 2013, p.15).

16 Recognition of the persistent gap has led to repeated suggestions on devolving tax (Birnie and Brownlow, forthcoming).

17 For overviews of different aspects of the Barnett formula see Heald (2003), Bell (2008) and Keep (2016).

18 For more details see the documents held in the file entitled 'Coal; financial arrangements for the payments of subsidies', T224/816 held by The National Archives.

19 There is merit in a supply-side diagnosis of the region's long-run economic predicament (PwC, 2011; Brownlow, 2013).

20 A historical observation is that the analysis of the 'Celtic Tiger' within the 'silver bullet' framework is overly simplistic. The Celtic Tiger was far more of a 'slow burn' process. As early as the mid-1950s profits were lightly taxed, but it was only approximately three decades later that this translated into greater levels of FDI (Barry, 2007). In any case, the effective rates of CT was much lower than the headline rates (Coffey, 2014).

21 The most forensic critique of the CT proposal can be found in (PwC, 2011).

22 Devolving any tax rate varying power must satisfy the European Court of Justice (ECJ) regarding the "Azores case". For a legal and public finance analysis of the 'Azores' case it is recommended that interested readers see (Holtham Report, 2009, pp.77-78 and Annex 5).

23 The vacuum however has been filled by business lobby groups and political parties. This observation on lobbying has parallels in Keaney and Hutton's earlier article (Keaney and Hutton, 2000).

24 This insightful observation was made by an anonymous referee.

25 Once again thanks are due to an anonymous referee for this point. 
Armstrong, H and Taylor, J. (2000) Regional economics and policy, Third Edition, Oxford, Blackwell.

Ashcroft, B. (1998) The economic possibilities for a Scottish Parliament, Regional Studies, 32: no.2.

Bailey, D and Budd, L. Eds (2016) Devolution and the UK economy, London, Rowman \& Littlefield.

Barry, F (2007) Foreign direct investment and institutional coevolution in Ireland, Scandinavian Economic History Review, 55, 262-288.

Bell, D (2008) Fiscal federalism in the UK, Stirling Economics Discussion Paper 15, University of Stirling.

Bell, D. (2016) The aftermath of the Scottish referendum: a new fiscal settlement for the United Kingdom? In Bailey, D and Budd, L. Eds (2016) Devolution and the UK economy, London, Rowman \& Littlefield.

Bell, D. and Eiser, D. (2014) Scotland's fiscal future in the UK, Working Paper, University of Stirling, Stirling, UK.

Birnie, E. and Brownlow, G. (forthcoming) Should the fiscal powers of the Northern Ireland Assembly be enhanced? Regional Studies.

Birnie, E. and Hitchens, D. (2001) Chasing the wind? Half a century of economic strategy documents in Northern Ireland, Irish Political Studies, 16, 1-27.

Booth, P. (2015) Federal Britain The case for decentralisation, London, Institute of Economic Affairs.

Brownlow, G. (2007) The causes and consequences of rent-seeking in Northern Ireland, 1945-72, Economic History Review, 60, 1.

Brownlow, G. (2013) Business and labour since 1945, in Kennedy, L. and Ollerenshaw, P. (Eds) Ulster since 1600: Politics, Economics and Society, Oxford, Oxford University Press.

Buchanan, J., Froud, J., Johal, S., Leaver. A and Williams, K., (2009) Undisclosed and unsustainable: problems of the UK national business model, CRESC Working Paper, University of Manchester, Manchester, UK.

Budd, L. (2016) Economic challenges and opportunities of devolved corporate taxation in Northern Ireland in Bailey, D and Budd, L. Eds (2016) Devolution and the UK economy, London, Rowman \& Littlefield.

Coffey, S. (2014) Effective rates of corporation tax in Ireland, Technical Paper, Dublin, Department of Finance.

Crafts, N. (1995) The golden age of economic growth in postwar Europe: why did Northern Ireland miss out? Irish Economic and Social History, 22, 5-25. 
Department of Finance and Personnel (2014) Northern Ireland net fiscal balance report 201112. Bangor, Department of Finance and Personnel.

Economic Advisory Group (EAG) (2016) Competitiveness Summary, July, Belfast, EAG.

Northern Ireland Economic Reform Group (ERGNI) (2010) the case for a reduced rate of Corporation Tax in Northern Ireland, Belfast, ERGNI.

Furniss, M (1975) Northern Ireland as a case study of decentralisation in unitary states, World Politics, 27: no.3.

Gallagher, J. (2016) Where next for Scotland and the United Kingdom? In Bailey, D and Budd, L. Eds (2016) Devolution and the UK economy, London, Rowman \& Littlefield.

Gardiner, B., Martin,R.., Sunley., P. and Tyler, P. (2013), Spatially unbalanced growth in the British economy, Journal of Economic Geography, 13; no.6.

Geary, F. and Stark, T. (2015) Regional GDP in the UK, 1861-1911: new estimates, Economic History Review, 68; no.1.

Geary, F. and Stark, T. (2016) What happened to regional inequality in Britain in the twentieth century? Economic History Review, 69; no.1.

Gibson, N. (1996) Northern Ireland and Westminster: fiscal decentralisation a public economics perspective in Decentralised Government and Economic Performance in Northern Ireland, Belfast, Northern Ireland Economic Council (NIEC).

Green, A. (1979) Devolution and public finance: Stormont from 1921 to 1972, Studies in Public Policy, No.48, Glasgow, University of Strathclyde.

Gudgin, G. (2017) The mechanics of the DUP deal, Policy Exchange, https://policyexchange.org.uk/the-mechanics-of-the-dup-deal (accessed July 3rd 2017).

Hamlin, A. (1991) Decentralization, competition and the efficiency of federalism, Economic Record, 67; no. 3 .

Harris, R. (1991) Regional economic policy in Northern Ireland 1945-1988, Aldershot, Avebury.

Heald, D. (2003) Funding the Northern Ireland Assembly: assessing the options (Research Monograph No.10), Belfast, Northern Ireland Economic Council (NIEC).

Independent Commission on Funding \& Finance for Wales [Holtham Report]. (2009), First report funding devolved government in Wales: Barnett \& beyond, Cardiff, Independent Commission on Funding \& Finance for Wales.

Kaldor, N. (1970) The case for regional policies, Scottish Journal of Political Economy, 17, 337-348.

Kay, A. and Marsh, A. (2007) The methodology of the Public Choice research programme: the case of "voting with feet", New Political Economy, 12: no.2.

Keaney, M. and Hutton, A. (2000) Devolved politics in a globalizing economy: the economic significance of the Scottish Parliament, Journal of Economic Issues, 34: no.2. 
Keep, M. (2016) The Barnett formula, House of Commons Library, Briefing Paper, Number 7386, 13 April 2016.

Lawrence, R. (1965) The government of Northern Ireland, Oxford, Clarendon.

Lee, C. (1995) Scotland and the United Kingdom, Manchester, Manchester University Press.

Mackay, R. (2003) Twenty-five years of regional development, Regional Studies, 37: no.3.

McCann, P. (2016) The UK regional - national economic problem geography, globalisation and governance, London, Routledge.

McCrone, G. (1999) Scotland's public finances from Goschen to Barnett, Quarterly Economic Commentary, 24(2), pp.30-46.

McCrone, G. (2014) Scottish Independence weighing up the economics, Edinburgh, Birlinn.

North, D. (1990) Institutions, Institutional Change and Economic Performance, Cambridge, Cambridge University Press.

Northern Ireland Council for Voluntary Action (NICVA) (2013) Fiscal powers: a review of the fiscal powers of the Northern Ireland Assembly, Belfast, NICVA.

Oates, W. (2005) Toward a second-generation theory of fiscal federalism, International Tax and Public Finance, 12, 349-373.

Office for National Statistics (ONS) (2015) Internal migration, England and Wales: year ending June 2015,

https://www.ons.gov.uk/peoplepopulationandcommunity/populationandmigration/migrationw ithintheuk/bulletins/internalmigrationbylocalauthoritiesinenglandandwales/yearendingjune20 15 (accessed July 4th 2017).

Ollerenshaw, P. (2013) Northern Ireland in the Second World War politics, economic mobilisation and society, 1939-45, Manchester, Manchester University Press.

Olson, M. (1965) The logic of collective action public goods and the theory of groups, London, Harvard University Press.

Pike, A, Rodríguez-Pose, A, Tomnaey, J., Torrisi, G., and Tselios, V. (2012) In search of the 'economic dividend' of devolution: spatial disparities, spatial economic policy, and decentralisation in the UK, Environment and Planning C: Government and Policy, 30, 10-28.

PricewaterhouseCoopers (PwC) (2011) Corporation tax: game changer or game over? Belfast, PwC.

Richardson, H. (1978) Regional \& urban economics, Harmondsworth, Penguin.

Rodríguez-Pose, A. and Gill, N. (2003) The global trend towards devolution and its implications, Environment and Planning C: Government and Policy, 21, 333-351.

Rodríguez-Pose, A. and Gill, N. (2004) Is there a global link between regional disparities and devolution? Environment and Planning A, 36, 2097-2117. 
Rodríguez-Pose, A. and Bwire, A. (2004) The economic (in) efficiency of devolution, Environment and Planning A, 36, 1907-1928.

Rodríguez-Pose, A. and Gill, N. (2005) On the 'economic dividend' of devolution, Regional Studies, 39, 405-420.

Rosen, H (2005) Public finance, seventh edition, New York, McGraw Hill.

Rowthorn, B. (1981) Northern Ireland: an economy in crisis, Cambridge Journal of Economics, 31, 1-31.

Rumbul, R. (2016) Commanding Economic Heights? The effects of constitutional uncertainty on Wales' fiscal future In Bailey, D and Budd, L. Eds (2016) Devolution and the UK Economy, London, Rowman \& Littlefield.

Tiebout, C. (1956) A pure theory of local expenditures, Journal of Political Economy, 64, 416-424.

Tomlinson, J. (2014) Imagining the economic nation: the Scottish case, Political Quarterly, 85:no.2.

Trench, A. (2013) Funding Devo More: fiscal options for strengthening the union, London, Institute for Public Policy Research (IPPR). 
Acknowledgement: There were no external sources of funding for this paper. 